\title{
South African Teachers' Beliefs and the Use of Manipulatives to Resolve the Concept-Symbol Schism in Mathematics Learning
}

\author{
Mantlhake J. Maboya ${ }^{1}$, Loyiso C. Jita ${ }^{2}$, Godsend T. Chimbi ${ }^{2, *}$ \\ ${ }^{1}$ Department of Basic Education, Pretoria, South Africa \\ ${ }^{2}$ Faculty of Education, School of Mathematics, Natural Sciences and Technology Education, University of the Free State, South Africa
}

Received July 22, 2020; Revised August 27, 2020; Accepted September 29, 2020

\section{Cite This Paper in the following Citation Styles}

(a): [1] Mantlhake J. Maboya, Loyiso C. Jita, Godsend T. Chimbi, "South African Teachers' Beliefs and the Use of Manipulatives to Resolve the Concept-Symbol Schism in Mathematics Learning," Universal Journal of Educational Research, Vol. 8, No. 11, pp. 5414 - 5424, 2020. DOI: 10.13189/ujer.2020.081144.

(b): Mantlhake J. Maboya, Loyiso C. Jita, Godsend T. Chimbi (2020). South African Teachers' Beliefs and the Use of Manipulatives to Resolve the Concept-Symbol Schism in Mathematics Learning. Universal Journal of Educational Research, 8(11), 5414 - 5424. DOI: 10.13189/ujer.2020.081144.

Copyright $\bigcirc 2020$ by authors, all rights reserved. Authors agree that this article remains permanently open access under the terms of the Creative Commons Attribution License 4.0 International License

\begin{abstract}
Many teachers of mathematics continue to struggle with the resolution of the concept-symbol schism for their learners, in part because the understanding of one depends on the other. Research has shown the benefits of using manipulatives to concretize abstract mathematical concepts and symbols, leading to the development of mathematics laboratories as an innovation to improve classroom pedagogical practice. This study examined mathematics teachers' beliefs about the use of manipulatives as instructional tools for learning. Using social constructivism and critical theory as the illuminating lens, primary school mathematics teachers in the Free State, South Africa, were case studied teaching 12-year-old Grades 6 learners in the context of newly established mathematics laboratories in their schools. Document analysis, semi-structured interviews and participatory lesson observations were used to gather data. The belief that mathematics is a difficult subject seemed prevalent and teachers largely used manipulatives in a mechanical manner which did not help to transcend the concrete representation of ideas. Despite the availability of well-resourced mathematics laboratories, the concept-symbol schism appeared unresolved in learners' minds. Teachers struggled to utilize the manipulatives to facilitate learners' cognitive transition from concrete to pictorial and abstract representations. Continuous professional development and lesson studies are recommended to help improve mathematics teachers'
\end{abstract}

content mastery and the use of manipulatives to nurture learners' understanding of abstract concepts and symbols.

Keywords Teacher Beliefs, Concept-Symbol Schism, Manipulatives, Pedagogy, Mathematics Laboratory, Concrete-Pictorial-Abstract Representations, Critical Theory

\section{Introduction}

The teaching and learning of mathematics, a subject considered the cornerstone of scientific and technological development, has always been complex and challenging; in part because mathematical knowledge is not intrinsic to teachers and students $[1,2,3,4,5]$. Most students find mathematics difficult because of the abstract nature of the subject and the way it is taught in schools. Larbi \& Mavis [3] stress that, "A major task for every mathematics teacher is how to make the subject meaningful to learners." More than two decades ago, Uttal, Scudder and DeLoache [6] argued that: "mathematics teachers face a double challenge. Symbols may be difficult to teach children who have not yet grasped the concepts that they represent. At the same time, the concepts may be difficult to teach to children who have not yet mastered the symbols." Mathematics teachers are therefore caught in a dilemma: what to introduce first to 
learners - the symbol or the concept? It becomes the chicken and the egg situation - what comes first? Of course, there are no easy answers; but the teacher's task (which is also not so easy) is to assist learners create a relationship between the symbols and the concepts they represent.

The abstract relationship between the concept and the symbol partly explains why mathematics teachers often resort to rote pedagogy $[1,3,7,46]$. In the traditional mathematics classroom, the teacher explains the new concepts and symbols while students listen. S/he demonstrates the facts and procedures on the chalkboard, followed by individual work. Learners are often reduced to passive sponges who absorb the procedures and facts, only to then mechanically reproduce them in the exercises given by the teacher. This makes mathematics difficult and boring to most learners.

Research has shown that students of all ages enjoy being taught mathematics through interactive and participatory methodologies that include the use of manipulatives $[8,9$, 10,11]. Manipulatives are concrete objects which students can see, touch and hear that act as visual representations of abstract mathematical concepts. Smith [12] defines manipulatives as "physical objects that are used as teaching tools to engage students in hands-on learning of mathematics." Manipulatives can be as simple as maize, wheat or rice grains, bottle tops or stone pebbles.

But it is critical for teachers and researchers to recognize that the mere presence of manipulatives does not guarantee learning $[8,10]$. Teachers need to understand how to use manipulatives first before they can help students create connections between the concrete materials available and the abstract concepts to be learnt. Manipulatives must be appropriate to the topic and carefully selected to stimulate students' thinking [2, 9]. Otherwise, the use of manipulatives can be a waste of time that creates confusion, making learners see the concrete media as simple toys. However, extant literature [3, 4, 9] has shown that students who use manipulatives in their lessons usually outperform those who do not; across all class levels, ability groups and topics.

The Free State Province of South Africa introduced mathematics laboratories (richly stocked with manipulatives) in 2011, as a strategy to improve the teaching and learning of mathematics in primary schools. The introduction of mathematics laboratories ignited many questions from both well-wishers and detractors. Policy makers and researchers have been asking for instance: How did teachers receive the introduction of mathematics laboratories in primary schools? Did the introduction of mathematics laboratories bring any substantive changes to the teaching and learning of mathematics in the schools, and if so how?

\section{Theoretical Framework}

This study taps into the dual framework of social constructivism and critical theory as illuminating lens. The two theories emerged as a result of the socio-political upheavals, wars, inequalities and uncertainties of the $19^{\text {th }}$ and $20^{\text {th }}$ centuries $[30,32,51]$. They both advocate for the freedom of learners from the tyranny of rote pedagogy; so that learners actively participate in their own learning and search for new knowledge [31,32, 48, 50]. The two theories challenge the traditional view that the teacher is the ordained source of knowledge and learners are passive recipients of processed knowledge.

Social constructivism emerged as a sociological theory in the $20^{\text {th }}$ century to explain the nature of reality. It is often associated with the work of Peter Berger and Thomas Luckman [51]; but its roots can be traced to $19^{\text {th }}$ century thinkers who include Karl Marx, Emile Durkheim and George Herbert Mead. Karl Mannheim (1893-1947), a pioneer of constructivism, argued that all ideas are products of their time and all the knowledge in the world is socially constructed as humans interact with one another and the environment [48]. Constructivists argue that no knowledge and reality can stand independent of its creators and the contexts in which it is created. The setting and context of the research (where, what, who, when, how and why) are very important for constructivists; because they believe that truth and reality are not universal but are situational and contextual [49]. When viewed from a constructivist perspective, instructional reform is a multi-layered concept because knowledge is seen as divergent, fluid and dynamic. This makes social constructivism an appropriate lens for exploring the use of manipulatives in mathematics laboratories; both of which are relatively new concepts in the teaching of mathematics. Prominent social constructivists include Lev Vygotsky, John Dewey, Jerome Bruner and Jean Piaget.

Critical theory has a complex tradition dating back to the early $20^{\text {th }}$ century. Its origins can be traced to a group of scholars at the Institute of Social Research in Frankfurt, Germany [30]. Critical theorists perceive the world as imperfect and unjust. The theory is rooted in the Marxist and neo-Marxist traditions and "the belief that society should work toward the ideals of equality and social betterment" [30]. Critical theory is preoccupied with issues of power, inequality and the quest for liberation. It advocates for the emancipation of the oppressed from an unjust socio-political-economic system that masks unequal relations under false meritocracy [31]. Critical theorists call for a reinterpretation of the world and its transformation to benefit the marginalised groups. Although the theory has often been associated with scholars in Europe, the United States and Canada; Ozlem and diAngelo [30] advise that: "Critical Theory's analysis of how society works continues to expand and deepen as theorists from indigenous, postcolonial, radicalized and other marginalized perspectives add layers to our collective understanding." Some of the contemporary proponents of 
this theory in education include Paulo Freire [31] and Michael Apple [32].

Social constructivism and critical theory were considered appropriate guides to this study because the use of manipulatives to transform classroom practice can best be analysed and understood from constructivist and critical perspectives. The two perspectives see reality as dynamic and co-constructed [31, 32, 48, 49, 50]. Critical theory is useful in making researchers gain insights into the inevitability and processes of pedagogical change; while social constructivism recognizes the collective deconstruction and reconstruction of knowledge through social interaction between teachers and learners. Teachers' experiences with manipulatives are bound to differ because of different contexts; making social constructivism and critical theory appropriate lens for illuminating the current study. The two related theories opened possibilities for the current study to examine teacher-pupil interactions in mathematics laboratories while using manipulatives to learn mathematics in novel ways.

\section{Problem Statement}

A lot of research has been conducted on the use of manipulatives in mathematics classrooms. But most of these studies have tended to focus on the effects of manipulatives on student performance and achievement [3, 4, 9, 10, 11, 46]. Experiments and/or quasi-experiments in these studies show the positive effects of manipulatives on student performance. The studies seem to suggest that learners taught using manipulatives consistently outperformed those taught through traditional chalk-and-talk methods.

Not much research, however, has been done on teachers' experiences with manipulatives and how these experiences shape their mathematical knowledge and classroom instruction. Carbonneau, Zhang and Ardasheva [13] point out that: "Little is known about the best ways to use manipulatives during instruction, and even less is known about how teachers perceive manipulatives and if their self-beliefs influence how often they plan to use manipulatives in the classroom.” The present study places teachers at the center of pedagogical reform in the mathematics laboratory. It interrogates how primary school teachers in the Free State utilized mathematics laboratories (and the manipulatives contained therein) as a reform initiative to improve their classroom pedagogical practice.

\section{Research Questions}

To examine the use of manipulatives in mathematics laboratories, two research questions undergird this paper:

1. What were the mathematics teachers' beliefs and knowledge on the use of manipulatives and mathematics laboratories for instructional improvement?

2. How did mathematics teachers use manipulatives to support the development of learners' concept-symbol relationship?

\section{Review of Related Literature}

\subsection{Mathematics as Difficult Terrain}

The poor performance of South African learners in Mathematics is well documented [20, 21]. In the TIMSS rankings of 2015, South Africa's Grade 9 learners were number 38 out of 39 participating countries with a score of 372 compared to the average score of 500 [15]. The Annual National Assessment (ANA) in Numeracy (Grade 3) and Mathematics (Grade 6) for 2010 were 28\% and 30\% respectively [23]. The Free State learners scored 26\% for Numeracy and 28\% for Mathematics in these examinations. The DBE [22] diagnostic report on the 2011 Grade 12 Mathematics results noted that many candidates struggled to understand mathematical concepts. Undoubtedly, these unpleasant results have direct implications on the instructional methods teachers use and the type of experiences learners go through in mathematics classrooms.

The search for the root cause of students' underachievement in mathematics has not spared mathematics teachers. In Indonesia, Hidayah, Dwijanto \& Istiandaru [19] gave 29 elementary school teachers two planar geometry problems and asked them to provide one-word answers. Only 38\% gave correct answers, 34\% gave wrong answers and $28 \%$ did not provide responses. The study showed that most teachers do not understand the mathematical concepts they teach to students, which may partly explain why students underperform in the subject. The current study sought to examine how manipulatives were used in mathematics laboratories to improve instructional practice in the Free State Province of South Africa.

\subsection{Types of Manipulatives}

Manipulatives come in various forms and shapes depending on the teacher's ingenuity. They range from simple stone pebbles, bottle tops, maize and rice grains; to sophisticated commercially manufactured models (like the solar system) that can be bought from stationery shops [12, $25,26,46]$. Teachers and students can bring manipulatives from home and/or improvise using inexpensive resources or waste materials readily available in their environment. Manipulatives commonly used to teach primary school mathematics include counters, abacus, spinners, cubes, triangles, balls, pattern blocks, scales, fraction strips, clocks, geometry boards, color and algebra tiles. Day \& 
Hurrell [10] point out that, "Manipulative materials are used to create an external representation that stands for a mathematical idea in order to eventually develop an internal representation.” Through seeing, touching and manipulation, students gain deeper and lasting understanding of mathematical concepts like numbers, operations, measurement, algebra and geometry across all grade levels. Using manipulatives, the teacher's role changes from that of a transmitter to a facilitator of learners' discovery; as they use concrete objects to explore, unpack and understand mathematical concepts and symbols.

\subsection{Role of Manipulatives}

Manipulatives enable the teacher and students to break away from the traditional classroom setting and instructional style by providing students with a hands-on-experience of mathematical concepts. Manipulatives can be used to introduce, practice and remediate concepts [2, 12, 28]. Research by psychologists Jean Piaget and Jerome Bruner has shown that children master concepts better when their thinking progresses through three hierarchical levels - the inactive (concrete), iconic (pictorial) and the symbolic (abstract) [5, 26, 27]. Manipulatives represent knowledge at the concrete level where learners can handle and manipulate objects to internalize mathematical processes and procedures. The teacher can then utilize this physical experience to develop more demanding mathematical cognitions using pictorial representations and finally symbols.

The way students use manipulatives also assists teachers to determine if students have any misunderstandings and misconceptions on the concepts they are learning. As students work with concrete objects, the teacher can "get inside students' heads" by asking probing questions that elicit their thinking and reasoning [28]. The teacher can then pick the problems students are encountering and intervene appropriately. Manipulatives have been found to be very useful in introducing and practicing many mathematical concepts. For instance, when introducing fractions, students can be asked to cut a block of wood into two equal parts (to develop the concept of halves); then into four equal parts (to develop the concept of quarters). The block can then be drawn on the board and notebooks and divided into halves and quarters; then the symbols $\frac{1}{2}$ and $\frac{1}{4}$ can be written. The proliferation of computers and the internet in the developed world has led to the use of virtual manipulatives in mathematics classrooms [10]. However, there is often a misplaced belief among some mathematics teachers that manipulatives make their work easier. If not correctly used, or when guidance from the teacher is inadequate, manipulatives can cause confusion and misconceptions in the learners' minds; creating more work for the teacher to clear the confusion and/or correct the misconceptions.

\subsection{Manipulatives: The Instructional Magic?}

Contrary to popular belief, manipulatives are not the instructional magic in mathematics. If their use is not properly guided by the teacher, manipulatives can cause confusion in learners' minds. For example, Day and Hurrell [10] quote some learners who defined a fraction as "a piece of pie to eat" because fractions are often represented in circle diagrams. Learners may fail to create a link between the concrete representation they are seeing/manipulating, and the abstract concept being taught. Larbi \& Mavis [3] caution that manipulatives must be used with care, "else students are made to believe two mathematical worlds exist; manipulative and symbolic.” It is essential to reiterate that the mere presence of manipulatives in the mathematics classroom does not guarantee meaningful learning.

Carbonneau, Zhang and Ardasheva [13] point out that; "manipulatives are not a panacea for all students in all situations and simple physical manipulations of blocks do not necessarily translate into student learning." The instructional efficacy of a manipulative is not embedded in the concrete object itself, but in the teacher's knowledge and ability to assist learners in creating connections and meaning between the objects being manipulated and the abstract concept they are learning. Moyer and Jones [29] found that teachers who have poor mathematical content knowledge often encourage learners to use manipulatives as simple toys and continue to teach using rote pedagogy. Ultimately, the successful use of manipulatives depends on the teacher's content knowledge of mathematics, instructional beliefs, creativity and lesson preparation, otherwise teachers can continue with didactic instruction while purporting to be using manipulatives.

\section{Research Methodology}

\subsection{Design}

This study took the qualitative critical theory approach. Denzin and Lincoln [33] advance that: "qualitative researchers study things in their natural settings, attempting to make sense of phenomena in terms of the meanings people bring to them." The use of manipulatives alters teacher-student relations by reducing learner dependency on the teacher allowing for emancipatory discourse [31]. Learners can create new knowledge and mathematical reality as they manipulate concrete objects. The research design for this study was Participatory Action Research (PAR). This model seeks to understand how teachers form and transform knowledge in a variety of settings [34]. PAR is often associated with social transformation in the developing world. Teachers in South Africa are a marginalized group whose voices are not always heard on matters that affect them [35]. This makes PAR an 
appropriate research design for this study because of its emancipatory and transformative stance; which dovetails with the critical theory framework illuminating this paper.

\subsection{Data Generation and Analysis}

Permission to conduct this study was granted by the University of the Free State (UFS) and the Free State Department of Education (FSDoE). The study targeted 19 primary schools in the Mangaung Metropolitan Municipality in the Free State; and three schools were purposively sampled. Patton [36] advises that it is important to select "information-rich" cases when conducting qualitative study. The selected schools were in the Motheo Education District and had fully resourced mathematics laboratories. The study targeted Grade Six learners and 41 teachers who were participating in the Instructional Leadership through Lesson Study programme which was conducted by the UFS in collaboration with the FSDoE. Purposive sampling was used to select three Grade Six teachers who had more than five years' experience in teaching mathematics in the Intermediate Phase (Grades 4 to 7). All Grade Six learners in the three classes directly participated in the study.

Three data collection instruments were used in this study viz; document analysis, semi-structured interviews and participatory lesson observations. The Curriculum and Assessment Policy Statement [24] and learners' written work were examined on how they (dis)empowered teachers and students.

The Free Attitude Interview technique [37] was used to collect data on teachers' beliefs about mathematics and the value of manipulatives in instruction. The technique enabled participants to air their views freely. Two lesson observations were conducted in the mathematics laboratory with each teacher. The intention was to examine how teachers used manipulatives to support the development of learners' concept-symbol relationship. The lessons were video recorded and field notes taken for later transcription by the first researcher. Lesson observations were also used to consolidate and cross-check the credibility of what the teachers said in the interviews. Qualitative data analysis involved organising, coding, explaining and making sense of the data gathered; identifying convergences and divergences; noting patterns, themes and categories.

\section{Results and Discussion}

Data analysis on teachers' beliefs on the use of manipulatives to support the development of learners' concept-symbol relationship resulted in the emergence of three themes which anchor the presentation and discussion of findings. The themes are teacher beliefs on the use of manipulatives; knowledge of mathematics; and the use of manipulatives in mathematics laboratories.

\subsection{Teacher Beliefs on the Use of Manipulatives}

Ms Dikgomo had six years' experience as a mathematics teacher in the Intermediate Phase (Grades 4-7) and was teaching mathematics to three of the four Grade 6 classes at her school. She had not trained to teach the Intermediate Phase, let alone to teach mathematics at that level. Her training was for the Foundation Phase (Grades 1-3) and she also had not passed mathematics at Grade 12.

In the interview Ms Dikgomo was asked to share her views on the use of manipulatives in teaching mathematics. She explained that: "It's not every topic in Mathematics that requires the use of manipulatives, sometimes you need the formula." Asked to give an example, she said: "My favourite topic in mathematics is multiple operations. It is because once the children know the rules, that is, BODMAS [Bracket, Of, Division, Multiplication, Addition, and Subtraction], then it is easy to get the answer. If they can only know where to start, there is nothing that will be difficult for them.” This conversation showed that Ms Dikgomo did not have much faith in the use of manipulatives. She viewed mathematics as a set of rules and procedures which learners must simply learn by heart (rote) to arrive at the correct answer.

Reflecting on her own primary mathematics experiences, Ms Dikgomo recalled how she learned BODMAS: "My teacher used to say when you do multiple operations, start by working those in brackets and division follows, then multiplication, addition and subtraction last. He used to say we should test if we'll get the same answer in the case of multiple operations.” Two major points emerged from this conversation. Firstly, Ms Dikgomo believed that mathematics is about mastering the rules of operations to get the correct answer. Secondly, teaching mathematics involves giving rules to learners which they must follow. Her concern appeared to be getting the correct answer. This belief contradicted the principles of social constructivism $[48,51]$ and critical theory [30, 31, 32]. The two theories advocate for the reduction of learner dependency on the teacher and empowering learners to become independent thinkers.

It is widely accepted that the teacher's personal beliefs and experiences in learning mathematics greatly influence classroom practice [38, 39, 40]. It is not surprising, therefore, that Ms Dikgomo's view of mathematics as a set of rules and procedures to be strictly followed, influenced her to teach mathematics using rote pedagogy, although she conducted lessons in a mathematics laboratory elaborately stocked with manipulatives. Interestingly, rote methods are often used to teach mathematics in many schools, not only in South Africa but the world over [19, 41, 42]. Larbi and Mavis [3] found that "Over one half of the students [in their study] reported never working in small groups to solve mathematical problems." Despite worldwide policy advocacy for learner-centric methods, the use of rote pedagogy appears widespread in many 
countries; reinforcing the pedagogy of the oppressed and learner subjugation [31].

Ms Bohata had 26 years' experience as a mathematics teacher. She had a Primary Teachers Diploma and had specialized in the Intermediate Phase (Grade 4-6). Her Grade 6 class had 57 mixed ability learners mainly from disadvantaged backgrounds. She explained that:

I never did mathematics at matric (Grade 12). I only did it up to Junior Certificate level (equivalent to the current Grade 9 because we were always reminded that mathematics is not for the faint hearted. We were scared off from mathematics because everybody believed that mathematics teachers were the strictest in school and were hard workers.

During her secondary school days Ms Bohata was made to believe that mathematics is a difficult subject. But her experiences with mathematics at the teachers' college made her develop the love for mathematics. She narrated that:

Our mathematics lecturer at the teachers' college used a lot of concrete teaching media. He taught mathematics in a practical way. I can say he is the one who introduced me to the use of manipulatives to teach abstract concepts. So, when I came to this school, no one was prepared to take mathematics at the Intermediate Phase as everybody regarded it as a difficult subject. The principal then requested me to teach only mathematics from Grade 6 to 7.

The belief that mathematics is a difficult subject seemed widespread at Ms Bohata's school. Literature also shows that mathematics phobia is widespread among teachers and students [5, 18, 39]. Syafriafdi et al. [14] report that, for most students, "mathematics sometimes becomes one of the scariest lessons." The fear of mathematics appears to be a global phenomenon which transcends Ms Bohata's school and national boundaries.

The performance of students in mathematics in international assessments like TIMSS and PISA [15, 16, 17] seems to buttress the popular belief that mathematics is not for every student, except the gifted. Some mathematics teachers also find the subject difficult to teach. In a study conducted by Tachie [18] in South African schools, one teacher confessed that: "All along a I have been struggling teaching some of the topics in class...Some of the teachers have [also] been experiencing problems with the concepts to be taught.” In a test administered to 29 elementary school teachers in Indonesia, only 38\% passed, 34\% failed and $28 \%$ did not provide responses [19]. It is sad to note that some teachers fail to solve mathematical problems they are expected to teach. This may partly explain why students perform poorly in mathematics because teachers cannot teach effectively what they do not know. But $\mathrm{Mr}$ Kopung's beliefs about mathematics appeared to be different from those of Ms Dikgomo and Ms Bohata.

Of the three participants in the current study, Mr Kopung is the only one who attempted mathematics at university level, although he dropped out after failing Calculus in first year. Mr Kopung had a Primary Teachers Diploma. He specialized in Mathematics and Natural Science for the Intermediate Phase (Grades 4-6) and had 24 years' experience as a mathematics teacher. Mr Kopung explained how he became a mathematics teacher:

I was good in mathematics at high school level and was trained as a mathematics teacher. But I developed the love for mathematics through my teaching experience. We used to have common marking centers for Standard 5 (equivalent of the current Grade 7) at cluster level. Because of the outstanding performance of my learners, and the shortage of mathematics teachers, I was identified by other teachers and school principals as the best mathematics teacher.

$\mathrm{Mr}$ Kopung's early turning point to mathematics appeared to influence his beliefs about mathematics and how the subject must be taught. He believed that problem-solving and the use of manipulatives are at the heart of mathematics learning and teaching. This is how he put it:

I like the fact that mathematics is a challenging subject, it makes you to think and be broad-minded. It is not like History where you cannot dispute the fact that Jan van Riebeek arrived in South Africa in 1652... In Mathematics there are always different ways of approaching a problem, looking at problems from different perspectives and using manipulatives to search for the answer. Mathematics keeps you on your toes; and with the introduction of the Annual National Assessments and the common tasks, you cannot relax. You want to sharpen your skills, teaching methods and knowledge in mathematics in order to be competitive and keep abreast with developments in the subject.

In contrast to Ms Dikgomo and Bohata, Mr Kopung saw mathematics as a dynamic and continually expanding field of knowledge which is challenging for both teachers and students and, therefore, requires the use of concrete objects to assist learners develop an understanding of the relationship between manipulatives and the abstract symbols they represent.

\subsection{Knowledge of Mathematics}

Ms Dikgomo had a generously stocked mathematics laboratory with commercial manipulates that included interlocking cubes, tangrams, color tiles, pattern blocks, fractions strips, multicolored balls, triangles, clocks and geoboards. But Ms Dikgomo started the lesson on 'Area' by writing the formula: Length $\mathrm{x}$ Width on the whiteboard. She explained that: "I want you to measure the length of this laboratory using the tape measures on your tables. After that you measure the width. And then multiple the two to get the area." 
Ms Dikgomo expected learners to merely know the formula so that they follow the step-by-step procedure to get to the correct answer. Her teaching approach contradicted the tenets of critical theory [30,31] which seeks to empower learners to be creators of their own mathematical knowledge. She did not mention the concept of 'surface area'. Rather she placed emphasis on the length and width of the classroom. Learners were then given the opportunity to measure and record the length and width of the mathematics laboratory they were in. The task was used to merely confirm the formula, and not to promote deeper understanding of the concept of area. Ms Dikgomo's knowledge of mathematics as a set of rules and procedures to be followed were reflected in her teaching which did not seek to explore and understand concepts in-depth.

The way Ms Dikgomo treated perimeter and area showed some knowledge gaps in her own understanding of the two related (but different) concepts. She was not able to bring out the differences between the two concepts, although she applied the correct formula for each. She emphasised to learners that to get the perimeter of a rectangle they use $\mathrm{L}+\mathrm{W}+\mathrm{L}+\mathrm{W}$. To calculate area, they use $\mathrm{L} \mathrm{x} \mathrm{W}$. But she did not explain why this is so and why the total area is written in square meters $\left(\mathrm{m}^{2}\right)$ and not just in meters, as is the case with parameter.

Like Ms Dikgomo, Ms Bohata also seemed not to have strong content knowledge of mathematics. In her scheme of work, Ms Bohata's lesson objective was "to do different kinds of 3 Dimensional (3D) shapes.” Her objective was ambiguous. She did not specify whether the lesson was on recognising, naming, describing or classifying 3D objects; as prescribed in the Intermediate Phase Mathematics Syllabus for Grade 6 [24].

Ms Bohata's mathematics laboratory was also fully stocked with a variety of commercially purchased manipulatives like number lines, hundreds charts, balance scales, geometric solids, protractors and teaching clocks. There were also improvised manipulatives that included used match boxes, juice cartons, cereal boxes, grain seeds and stone pebbles collected by the teacher and students. But she asked oral questions when she introduced the lesson on properties of 2D shapes. Verbally she created a link between the different shapes learners already knew and the new topic. It only became apparent as the lesson progressed that the lesson was on the different kinds of prisms as a category of 3D shapes. However, Ms. Bohata used the terms 3D shapes and prisms interchangeably. This misconception permeated the whole lesson. Ma [42] points out that the knowledge of mathematics goes beyond mere facts, principles and procedures. It involves an understanding of the similarities and differences between related concepts. Ms. Bohata seemed to have limited knowledge on how prisms differed from other 3D shapes, which may explain why she used the two concepts interchangeably. Research done in Lesotho primary schools by George et al. [40] reveals that; "there are some teachers who have never passed Mathematics and Science at any level of education examined nationally, thus making it difficult and uncomfortable for these teachers to teach these subjects effectively." This was exactly the case with Ms Dikgomo and Ms Bohata - both had not passed mathematics at Grade 12. But they were teaching the subject at Grade 6 level.

Ms Bohata also failed to make explicit connections between 2D and 3D shapes, and to provide reasons for the connections. She could have explained, for example, how polyhedrons (a family of 3D shapes) are made up of polygons (a family of 2D shapes); and how the properties of polygons have a bearing on the name and properties of polyhedrons. Ms Bohata's inability to explicitly locate 3D shapes within the wider scope of 2D shapes demonstrated her insufficient knowledge of the topic she was teaching. Research by Hidayah et al. [19] George et al. [40] and Tachie [18] shows that, oftentimes, mathematics teachers lack the content knowledge of the topics they teach, thereby limiting the opportunities to learn mathematics they can provide to their students.

The mathematics laboratory in which Mr Kopung was conducting lessons had concrete manipulatives of different types, sizes and quantities. They included pattern blocks, fraction strips, protractors, number lines, multiplication tables, and geometric solids. He used geometric cubes and rectangular prisms to engage learners in mathematical conversation on what was similar and different between the $3 \mathrm{D}$ shapes. Where learners struggled to grasp concepts like edges, vertex and vertices he used manipulatives to physically illustrate each of these concepts to clarify the concept-symbol relationship. Mr Kopung would stop class activity to explain concepts and emphasize the relationship between the concrete manipulative and the abstract concepts of 3D shapes. He seemed conversant with the Grade 6 mathematics content he was teaching. For instance, he made efforts to ensure that learners used correct mathematical terminology. Where learners used phrases "upper and bottom sides"'; and "right and left sides" to refer to the sides of a rectangle that are equal, he stressed that the correct term was "opposite sides." His emphasis on the use of appropriate mathematical terminology, while using manipulatives to illustrate the point, helped in eliminating possible misconceptions and errors that could occur if learners continued to use "left and right sides" or "upper and bottom sides" to describe different shapes.

Unlike Ms Dikgomo and Ms Bohata, Mr Kopung seemed to explain mathematical concepts to learners more clearly. He also created opportunities for learners to discover new mathematical knowledge while holding manipulatives in their hands. This practice was in line with the theory of social constructivism which encourages learners to understand concepts rather than memorize them $[50,51]$. This could have been because Mr Kopung had taken mathematics at Grade 12 and passed it. He had also trained as a mathematics and science teacher for 
intermediate phase classes and, more importantly, he believed that mathematics involves problem solving and he loved to teach the subject. George et al. [40] point out that effective mathematics teachers use appropriate representations, examples and explanations to illustrate mathematical concepts and symbols to learners.

\subsection{Use of Manipulatives in Mathematics Laboratories}

Data on the use of manipulatives in mathematics laboratories were gathered through interviews and lesson observations. Ms Dikgomo was observed teaching fractions in a well-equipped mathematics laboratory which had interlocking cubes, fraction circles, fraction strips, geometric boards and Cuisenaire rods. She asked learners to identify fractions they could remember. They picked on: half, a third, three quarters and a fifth. It was evident that Ms Dikgomo wanted to establish learners' prior knowledge on fractions. She then directed learners to use interlocking cubes to demonstrate each of the fractions they had listed. Learners were able to make concrete representations of the different fractions. Manipulatives were used to illustrate concrete examples of fractions only. Ms Dikgomo seemed to get trapped in the simplistic use of manipulatives. Manipulatives were used at the concrete level only; instead of taking learners through the Concrete-Pictorial-Abstract (C-P-A) levels of representation [27, 43]. She then demonstrated how fractions were added stressing the importance of a common denominator, after which learners were given work to do.

Ms Dikgomo focused more on procedures and steps to be followed in adding fractions to get to the correct answer, than the nurturing of learners' conceptual understanding. Her focus on procedural knowledge seemed to conflict with the National Curriculum Statement's aim of developing deep conceptual understanding of mathematics [24]. Viewing mathematics as a set of rules made her adopt the drill and practice approach making learners regurgitate the steps towards the correct answer.

The mathematics laboratory in which Ms Bohata was observed teaching was elaborately stocked with counters, abacus, fraction circles, fraction strips, pattern blocks, colour tiles, unifix cubes, interlocking cubes, Cuisenaire rods and geoboards. Ms Bohata afforded learners the opportunity to use manipulatives that were in the mathematics laboratory to construct 3D models. This aligned with critical theory [30, 31, 32] and social constructivism [48, 49, 50, 51] which advocate for knowledge construction by learners. She created opportunities for learners to construct 3D models using concepts such as: the base, vertex, edge, faces and sides. Learners linked the 2D shape names with the corresponding prism names. Through this activity, Ms Bohata afforded learners the opportunity to identify the properties of prisms, count the faces, edges and vertices. She guided learners to realize that the edges and the vertices are represented by the zoom struts and the nodes respectively.

Ms Bohata asked learners to count the faces of the prisms. However, this appeared confusing as learners counted in a haphazard manner. At this point the first researcher, who was a participant observer, intervened. She asked learners to identify the shapes in the triangular prisms they were holding. They pointed out that the triangular prism had triangles and rectangles. To clear the confusion, the researcher asked learners to count the number of triangles first and then the rectangles; and add the two. They did that and concluded that the total number of faces in the triangular prism was five. Dwijanto \& Istiandaru [19] point out that: "the use of manipulatives which is integrated with a series of written and oral questions is effective and practical to improve the students' concept understanding in the solid geometry learning.” Ms Bohata appeared to miss the element of combining the use of manipulatives with oral questions to deepen students' understanding of abstract geometrical concepts. Therefore, the researcher had to intervene and assist learners to create the link.

The mathematics laboratory at Mr Kopung's school was generously stocked with manipulatives of all types and colours ranging from counters, abacuses, cubes, triangles, pattern blocks, scales, fraction strips, clocks to geometry boards. Mr Kopung's used different mathematical representations such as skeletons of 3D shapes, struts and nodes, and diagrams of $3 \mathrm{D}$ shapes to facilitate the construction of 3D solids. He directed learners to use struts and nodes to construct models of prisms like cubes, rectangular prisms, triangular prisms, hexagonal prisms. Through this practical activity learners physically constructed the 3D models in small groups providing opportunities for discussion. Mr Kopung's teaching methods were aligned to critical theory [31, 32] which seeks to empower students to construct their own mathematical reality and knowledge. In one group that was constructing a triangular prism, an argument ensued after one learner constructed a pyramid and insisted that it was a triangular prism because all faces were made up of triangles. Instead of listening and joining the debate, $\mathrm{Mr}$ Kopung just told the group to use a rectangle as a base for the construction of the triangular prism. In another group there were arguments about the size of struts to be used in a single model. Upon hearing the arguments, Mr Kopung stopped everybody and said: "Construct a 3D shape using long blue struts of equal length.” He did not use students' arguments to explore the concept of 3D shapes in greater depth.

But when learners presented their concrete models, $\mathrm{Mr}$ Kopung projected the relevant diagrams from the computer to the screen; affording learners the opportunity to visualize the prisms in pictorial form. He deliberately linked the diagrams to the 3D models learners had constructed. Commendable efforts were made to use 
multiple representations of concepts to reinforce the Concrete to Pictorial to Abstract (C-P-A) transition in the learners' minds [27, 43]. The C-P-A approach helps to promote transition from concrete manipulation to the creation of mental images of the concepts in the students' minds; and then the development of the symbolic notation representing the concept.

Mr Kopung also initiated discussions with students to explore the salient features of geometrical shapes and make them explicit to promote deeper understanding. Ma [42] notes that Chinese teachers prefer to engage students in discussions after the use of manipulatives. There is consensus among scholars $[43,44,45]$ that manipulatives can be used to facilitate deeper understanding of geometrical terms and concepts. This is what Mr Kopung was doing, demonstrating his mathematics content and pedagogical knowledge superiority, over that of Ms Dikgomo and Bohata. His efforts to empower students with knowledge to solve mathematical problems, with minimum assistance from the teacher, also aligned with critical theory [30, 31, 32] which is the illuminating lens for this study.

\section{Conclusions}

This study on mathematics teachers' beliefs and use of manipulatives in mathematics laboratories has shown that the existence of richly stocked mathematics laboratories does not guarantee the effective use of manipulatives for the benefit of learners. Hidayah et al. [19] argue that, sometimes, manipulatives may distract students from internalizing abstract concepts embedded in the concrete objects. Larbi \& Mavis [3] also caution that manipulatives (if not properly used) can mislead students to believe that two mathematical worlds exist: the concrete and the symbolic. Two teachers in the current study used manipulatives in a rather mechanical manner. But $\mathrm{Mr}$ Kopung made efforts to encourage students to be constructers of their own mathematical knowledge and reality. The other two teachers did not go beyond the concrete representation of mathematical concepts, leaving the concept-symbol conundrum largely unresolved. This study showed the need for teachers to improve their mathematical content mastery and pedagogical content knowledge if they are to utilize concrete objects to nurture learner transition from concrete to pictorial and then abstract reasoning.

Although the development of mathematics laboratories is a novel curriculum reform initiative in South African primary schools, their utilization to improve performance in mathematics is dependent on teacher knowledge and efficacy. This study, therefore, recommends continuous professional development to revamp teachers' content knowledge of mathematics and the use of manipulatives to support the concept-symbol relationship in the learners' minds. Lesson studies on the use of manipulatives can also be initiated to nurture learners' cognitive transition from concrete to pictorial and then symbolic representation of abstract concepts and symbols. Mathematics laboratories can degenerate into museums and manipulatives into toys if mathematics teachers' content and pedagogical knowledge are not enhanced to ensure the full utilization of these pedagogical innovations.

\section{Acknowledgements}

This article is generated from an unpublished $\mathrm{PhD}$ thesis: Maboya, M.J. (2014). The relationship between teachers' mathematical knowledge and their classroom practices: A case study on the role of manipulatives in South African primary schools. University of the Free State, Bloemfontein, South Africa. https//scholar.ufs.ac.za/handle/11660/783

\section{REFERENCES}

[1] K.M. White. The effect of an instructional model utilising hand-on learning and manipulatives on math achievement of middle school students in Georgia, Unpublished Doctoral Thesis. Liberty University. 2012.

[2] K.J. Carbonneau, S.C. Marley, J.P. Selig. A meta-analysis of the efficacy of teaching mathematics with concrete manipulatives, Educational Psychology, Vol.10, No.2, 380-400, 2013.

[3] E. Larbi, O. Mavis. The use of manipulatives in mathematics education, Journal of Education and practice, Vol.7, No.36, 53-61, 2016.

[4] L.J. Uribe-Florez, J.L.M. Wilkins. Manipulative use and elementary school students' mathematics learning, International Journal of Science and Mathematics Education, Vol.15, 1541-1557, 2017.

[5] B. Ubuz, B. Erdogan. Effects of physical manipulation instructions with or without explicit metacognitive questions on geometrical knowledge acquisition, International Journal of Science and Mathematics Education, Vol.17, 129-151, 2019.

[6] D.H. Uttal, K.V. Scudder, J.S. DeLoache. Manipulatives as symbols: A new perspective on the use of concrete objects to teach mathematics, Journal of Applied Developmental Psychology, Vol.18, 37-54, 1997.

[7] J.A. Fletcher. Learning algebraic concepts through group discussion, Journal of Science and Mathematics Education, Vol.4. 31-47. 2009.

[8] K. Reimer, P.S. Moyer. Third graders learn about fractions using virtual manipulatives: A classroom study, Journal of Computers in Mathematics and Science Teaching, Vol.24, No.1, 5-25, 2005.

[9] J. Strom. Manipulatives in mathematics instruction, A 
research paper submitted to the Department of Mathematics and Computer Science, Bemidji State University, Minnesota, 2009.

[10] L. Day, D. Hurrell. Food for thought: The role of manipulatives in the teaching of fractions, Australian Primary Mathematics Classroom, Vol.22, No.4, 39-40, 2017.

[11] T. Stiegelmeier, J.D. Moore. Effective mathematics instruction for Native American elementary students: Strategies for using manipulatives, Journal of Teacher Action Research, Vol.5, No.3, 99-111, 2019.

[12] S.S. Smith. Early childhood mathematics using manipulatives. (4 ${ }^{\text {th }}$ Ed.), Pearson Education, Boston, 2009.

[13] K.J. Carbonneau, X. Zhang, Y. Ardasheva. Preservice educators' perceptions of manipulatives: the moderating role of mathematics teaching efficacy, School Science and Mathematics, 1-10, 2018.

[14] N. Syafriafdi, A. Fauzan, I.M. Arnawa, S. Anwar, W. Widada, The tools of mathematics learning based on realistic mathematics education approach in elementary school to improve math abilities, Universal Journal of Educational Research, Vol.7, No.7, 1532-1536, 2019.

[15] V. Reddy, M. Visser, L. Winnaar, F. Arends, A. Juan, C.H. Prinsloo, K. Isdale. Highlights of mathematics and science achievement of Grade 6 South African learners, Human Research Council, Pretoria, 2016.

[16] K.Y. Amy Lee. Improving Ontario mathematics performance: A comparative study of underlying factors for mathematics achievements in Ontario-Canada, Singapore and Shanghai-China, Master's Thesis, Harvard University, Cambridge, 2017.

[17] P. Smith, M. Ladewig, R. Prinsley. Improving the mathematics performance of Australia' students, Office of the Chief Scientist Occasional Paper, Australian Government, 1-8, Canberra, 2018.

[18] S.A. Tachie. Teachers' attitudes towards lesson study as a viable strategy to improve the teaching and learning of mathematics, Universal Journal of Educational Research, Vol.8, No. 6, 2326-2334, 2020.

[19] I. Hidayah, Dwijanto, A. Istiandaru. Manipulatives and question series for elementary school mathematics teaching on solid geometry, International Journal of Instruction, Vol.11, No.3, 649-662, 2018.

[20] DoE (Department of Education). Trends in Education Macro-Indicators Report, Department of Education, Pretoria, 2009.

[21] I.A. Salami, C.I.O. Okeke. Transformation and decolonisation of mathematics education for sustainable development: A case study of its learning trend in Nigeria, Perspectives in Education, Vol.35, No.2, 45-59, 2017.

[22] DBE (Department of Basic Education). Report on the National Senior Certificate Examination 2011: National Diagnostic Report on Learner Performance, Pretoria, 2011a.

[23] DBE (Department of Basic Education). Report on the Annual National Assessments of 2011, Department of Basic Education, Pretoria, 2011b.
[24] DBE (Department of Basic Education). Mathematics: Curriculum and Assessment Policy Statement Grades 4-6, Department of Basic Education, Pretoria, 2011c.

[25] M. Boggan, S. Harper, A. Whitmore. Using manipulatives to teach elementary mathematics, Journal of Instructional Pedagogies, Vol.3, 1-6, 2010.

[26] J.M. Furner, N.L. Worrell. The importance of using manipulatives in teaching maths today, Transformations, Vol.3, No.1, 1-26, 2017.

[27] H, Kurniawan, Budiyono, Sajidan, Siswandari. Concrete-Pictorial-Abstract approach on student's motivation and problem-solving performance in algebra, Universal Journal of Educational Research, Vol. 8, No.7, 3204-3212, 2020.

[28] National Council of Teachers of Mathematics (NCTM) Standards and focal points, 2000. Available at: http://www.nctm.org/standards/default.aspx?id_58

[29] P.S. Moyer, M.G. Jones. Teachers, students, and manipulatives in mathematics classrooms, Social Science and Mathematics, Vol.104, 16-31, 2004.

[30] S. Ozlem, R. DiAngelo. Is everyone really equal? An introduction to key concepts in social justice $\left(2^{\text {nd }} \mathrm{Ed}\right)$, Teachers College Press Columbia University, New York, 2017.

[31] P. Freire. Pedagogy of the oppressed (30 ${ }^{\text {th }}$ Anniversary Ed.), Bloomsbury, London, 2000.

[32] M.W. Apple. Ideology and curriculum ( $3^{\text {rd }}$ Ed.), Routledge and Palmer, New York, 2004.

[33] N.K. Denzin, Y.S. Lincoln. Introduction: The discipline and practice of qualitative research, In N.K. Denzin, Y.S. Lincoln, (Eds), Handbook of qualitative research ( $\left.{ }^{\text {nd }} \mathrm{Ed}.\right)$, Sage, Thousand Oaks, 2000.

[34] S. Kemmis, R. McTaggart. Participatory action research: Communicative action and the public sphere, In N.K. Denzin, Y.S. Lincoln (Eds), Handbook of qualitative research ( $2^{\text {nd }} E d$.), Sage, Thousand Oaks, 2000.

[35] A. Carl. The "voice of the teacher" in curriculum development: a voice crying in the wilderness? South African Journal of Education, Vol.25, No.4, 223-228, 2005.

[36] M.Q. Patton. Qualitative evaluation checklist: Evaluation checklist project, 1-13, 2003.

[37] L. Cohen, L. Manion, K. Morrison. Research methods in education (7th Ed.), Routledge, London, 2011.

[38] C.S. Wallace, N. Kang. An investigation of experienced secondary science teachers' beliefs about inquiry: An examination of competing belief sets, Journal of Research in Science Teaching, Vol.41, No.9, 936-960, 2004.

[39] A.E. Foley, J.B. Herts, F. Borgonovi, S. Guerriero, S.C. Levine, S.L. Beilock. The math anxiety-performance link: A global phenomenon, Current Directions in Psychological Science, Vol.26, No.1, 52-58, 2017.

[40] M.J. George, M. Kolobe, E.K. Moru. Exploring the mathematics and science subject matter content in the primary school level in Lesotho teachers, International Journal of Science and Technology Educational Research, 
Vol.9, No.2, 9-17, 2018.

[41] J. Cai, B. Perry, N. Wong, T. Wong. What is effective teaching? A study of experienced mathematics teachers from Australia, the mainland China, Hong Kong-China and the United States, In Cai, J., Kaiser, G., Perry, B. and Wong, N. (Eds), Effective mathematics teaching from teachers' perspectives: National and Cross-national studies, 1-36, 2009.

[42] L. Ma. Knowing and teaching elementary mathematics: Teachers' understanding of fundamental mathematics in China and the United States (Anniversary Ed.), Routledge, London, 2010.

[43] K.W. Kosko, L.M. Wilkins. Mathematical communication and its relation to the frequency of manipulative use, International Electronic Journal of Mathematics Education, Vol.5, No.2, 79-90, 2010.

[44] H. Miranda, J. Adler. Re-sourcing mathematics teaching through professional development, Pythagoras, Vol.72, 14-26, 2010

[45] G. Sidhu, S. Srinivasan. An intervention-based active-learning strategy to enhance student performance in mathematics, International Journal of Pedagogy and Teacher Education, Vol.2, No.1, 85-96, 2018.

[46] Z. Kablan. The effects of manipulatives on mathematics achievement across different learning styles, Educational Psychology, Vol.36, No.2, 277-296, 2016.

[47] A. Mirza, N. Hussain. Performing below the targeted level: An investigation into KS3 pupils' attitudes towards mathematics, Journal of Education and Educational Development, Vol.5, No.1, 8-24, 2018.

[48] U. Flick. An Introduction to qualitative research (5 ${ }^{\text {th }}$ Ed.), Sage, London, 2014.

[49] M. D. Gall, J.P. Gall, W.R. Borg. Educational research: An introduction ( $8^{\text {th }}$ Ed.). Pearson, Boston, 2007.

[50] S.R. Ponelis. Using interpretive qualitative case studies for exploratory research in Doctoral Studies: A case of information systems research in small and medium enterprises. International Journal of Doctoral Studies, Vol. 10, 535-550, 2015.

[51] P.L. Berger, T. Luckman. The social construction of reality: A treatise in the sociology of knowledge. Penguin, London, 1966. 